\title{
Background story of the cover picture
}

\section{Thomas van Gulik}

Department of Surgery, Amsterdam University Medical Centers, University of Amsterdam, Amsterdam, The Netherlands

Correspondence to: Thomas van Gulik. Department of Surgery, Amsterdam University Medical Centers, University of Amsterdam, Amsterdam, The Netherlands. Email: t.m.vangulik@amsterdamumc.nl.

Submitted Mar 10, 2021. Accepted for publication Mar 21, 2021.

doi: 10.21037/hbsn-2021-11

View this article at: http://dx.doi.org/10.21037/hbsn-2021-11

The cover image shows the anatomy lesson of Dr. Frederick Ruysch (1638-1731), one of the pioneers in disclosing the anatomy of the lymphatic system. The painting was made by Adriaen Backer in 1670 in Amsterdam, depicting Ruysch (third from the left) during an anatomical demonstration of the inguinal lymph nodes. He was the first to show these nodes and also the valves in the lymphatic vessels. Ruysch is surrounded by surgeon-governors of the Amsterdam Surgical Guild, who had commissioned the artist to make this painting of themselves as a group portrait, while attending the anatomy lesson. The corpse was of a criminal who was sentenced to death and after the execution, was handed over to the surgeons for this anatomy lesson. Frederick Ruysch was a famous Dutch, $17^{\text {th }}$ century physician and anatomist who was appointed by the city council to teach anatomy to the members of the Surgical Guild. Ruysch was internationally renowned for his great anatomical skills and his innovative techniques to preserve anatomical specimens. With his work on visualization of the lymphatic system, he contributed to the early history of 'lymphatic anatomy'.

The painting (canvas $168 \times 244 \mathrm{~cm}$ ) is exhibited in the Amsterdam Museum in Amsterdam, The Netherlands.

For further reading, see: IJpma FF, van Gulik TM. "Anatomy lesson of Frederik Ruysch" of 1670: a tribute to Ruysch's contributions to lymphatic anatomy. World 7 Surg 2013;37:1996-2001.

\section{Acknowledgments}

Funding: None.

\section{Footnote}

Provenance and Peer Review: This article was commissioned by the editorial office, Hepatobiliary Surgery and Nutrition. The article did not undergo external peer review.

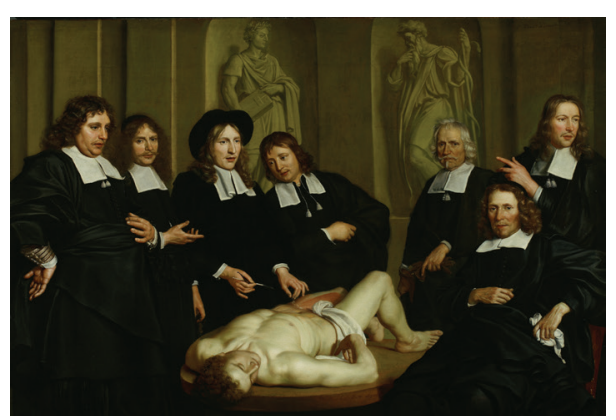

Conflicts of Interest: The author has completed the ICMJE uniform disclosure form (available at https://hbsn. amegroups.com/article/view/10.21037/hbsn-2021-11/ coif). TMvG serves as an unpaid editorial board member of Hepatobiliary Surgery and Nutrition. The author has no other conflicts of interest to declare.

Ethical Statement: The authors is accountable for all aspects of the work in ensuring that questions related to the accuracy or integrity of any part of the work are appropriately investigated and resolved.

Open Access Statement: This is an Open Access article distributed in accordance with the Creative Commons Attribution-NonCommercial-NoDerivs 4.0 International License (CC BY-NC-ND 4.0), which permits the noncommercial replication and distribution of the article with the strict proviso that no changes or edits are made and the original work is properly cited (including links to both the formal publication through the relevant DOI and the license). See: https://creativecommons.org/licenses/by-nc-nd/4.0/.

Cite this article as: van Gulik T. Background story of the cover picture. HepatoBiliary Surg Nutr 2021;10(2):153. doi: 10.21037/hbsn-2021-11 